Araştırma Makalesi / Research Article

Tarla Bitkileri / Field Crops

DOI: $10.21597 /$ jist.458477
Iğdır Üniversitesi Fen Bilimleri Enstitüsü Dergisi, 9(1): 545-551, 2019

Journal of the Institute of Science and Technology, 9(1): 545-551, 2019

ISSN: 2146-0574, eISSN: 2536-4618

\title{
Assessment of Yield and Quality of Some Triticale Genotypes in South-Eastern Anatolia
}

\author{
Ferhat KIZILGEÇ. $\dot{I}^{1 *}$
}

\begin{abstract}
This research was conducted to assess of yield and its component in different locations some triticale genotypes. The field experiment was arranged to the randomized complete block design with four replications during the 2012-13 growing seasons under Diyarbakir and Mardin ecological conditions. Three triticale cultivars (Ege Yildizi, Fahad-5 and Karma 2000) and two advanced lines (Line DZT-01 and Line DZT-06) were used as material. SPAD, protein content, test weight, thousand kernel weight, starch content, wet gluten, zeleny sedimentation and grain yield were evaluated. According to the findings of research, genotypic differences were found significant for SPAD, grain yield, thousand kernel weight and test weight. The values ranged in genotypes were between 51.8-57.3 in SPAD, 5043.9-6469.3 $\mathrm{kg} \mathrm{ha}^{-1}$ in grain yield, 35.31-45.81 $\mathrm{g}$ in thousand kernel weight, $71.38-78.72 \mathrm{~kg} \mathrm{hL}^{-1}$ in test weight, $13.1-13.7 \%$ in protein content, $64.27-65.94 \%$ in starch content, $28.71-30.61 \%$ in wet gluten and 40.42-45.67 mL in zeleny sedimentation. Significant positive correlation between protein content with gluten content and zeleny sedimentation in both locations was found. With regard to grain yield and some quality traits of Line DZT01 and quality traits of Line DZT-06 were highest than commercial cultivars in both locations. Line DZT01 and Line DZT-06 were found as promising line. These lines can be new cultivar candidates and could be recommended to sown in South-Eastern Anatolia Region of Turkey.
\end{abstract}

Keywords: Triticale, grain yield, protein content, SPAD,

\section{Güneydoğu Anadolu'da Bazı Tritikale Genotiplerinin Verim ve Kalitesinin Değerlendirilmesi}

ÖZET: Bu araştırma bazı tritikale genotiplerinin farklı lokasyonlarda verim ve verim unsurlarını belirlemek için yürütülmüştür. Tarla Denemeleri, 2012-13 üretim sezonunda Diyarbakır ve Mardin ve ekolojik koşullarında tesadüf blokları deneme desenine göre dört tekrarlamalı olarak kurulmuştur. Materyal olarak 3 ticari tritikale çeşidi (Ege Yıldızı, Fahad-5 and Karma 2000) ve iki ileri tritikale hattı (Hat DZT-01 ve Hat DZT-06) kullanılmıştır. Çalışmada SPAD, protein içeriği, hektolitre ağırlığı, bin tane ağırlığı, nişasta içeriği, yaş glüten, zeleny sedimantasyon ve tane verimi özellikleri incelenmiştir. Çalışmadan elde edilen sonuçlara göre, SPAD 51.8-57.3, tane verimi 5043.9-6469.3 kg ha-1, bin tane ağırlı̆̆ 35.31-45.81 g, hektolitre ağırlı̆̆ $71.38-78.72 \mathrm{~kg} \mathrm{hL}^{-1}$, protein içeriği \%13.1-13.7, nişasta içeriği \%64.27-65.94, glüten içeriği \%28.71-30.6 ve zeleny sedimantasyon 40.42-45.67mL değerleri arasında değişim göstermiştir. Her iki lokasyonda da protein içeriği ile yaş glüten ve zeleny sedimantasyon özellikleri arasında olumlu ve önemli ilişki belirlenmiştir. İleri tritikale hatları tane verimi ve kalite özellikleri yönünden ticari çeşitlere göre her iki lokasyonda da üstün bulunmuşlardır. Bu nedenle Hat DZT-01 ve Hat DZT-06 yeni çeşit aday1 ve Güneydoğu Anadolu bölgesinde ekimi tavsiye edilebilir genotipler olarak belirlenmişlerdir.

Anahtar kelimeler: Tritikale, tane verimi, protein içeriği, SPAD

\footnotetext{
${ }^{1}$ Ferhat KIZILGEÇİ, (Orcid ID: 0000-0002-7884-5463), Mardin Artuklu Üniversitesi, Kızıltepe Meslek Yüksek Okulu, Bitkisel ve Hayvansal Üretim Bölümü, Mardin, Türkiye

* Sorumlu Yazar/Corresponding Author: Ferhat KIZILGEÇİ, e-mail: ferhat_kizilgeci@hotmail.com 


\section{INTRODUCTION}

Triticale is an established small grain cereal crop that combines the productivity of wheat with the hardiness of rye. Triticale (genus $\mathrm{X}$ Triticosecale) was developed by human intervention from crosses between wheat (genus Triticum) and rye (genus Secale). Triticale yields more than its ancestors in two types of marginal conditions such as in the highlands, acid soils, phosphorus deficit soil and high disease foliar severity; and also possible to grow water deficit in the arid and semi-arid condition. Although triticale is grown in many countries of around the world, while the major producers are Poland and Germany, Belarus and France, respectively. According to the data on FAO, (2016) triticale was produced 15.2 million tons from 4.1 million ha land around the world; where, 125000 tons grains were produced from 37621 ha land in Turkey. Triticale has a similar role to other cereals. Triticale is higher in energy than barley, and has many desirable nutritional characteristics for all classes of livestock. Small amount of triticale is used for human consumption such as for breakfast cereals, biscuits and cakes. Triticale is better suited to the production of biofuel than wheat. Meyer and Lorenzo del Rio (2004) reported that triticale grain is mostly used for livestock diets. Triticale is a profitable crop because of carries some good characteristics from wheat and rye and can be use in human feeding, however average yield of triticale is very low in Turkey as compared with other producing countries across the globe. Therefore, well managed improvement programs must be conducted for improving in different new varieties in different places under climate and soil conditions. The most important thing that programs need is having the material with different characteristic that able to use as genetic sources. These kind of materials might be useful if they were revealed their characteristics and performances in different ecologies. In this study, grain yield and quality traits of some triticale and relationships of these traits have been evaluated under rainfed conditions of Diyarbakir and Mardin.

\section{MATERIALS AND METHODS}

\section{Locations and agro-climatic condition}

The present study was conducted at Diyarbakir (latitude $37^{\circ} 88^{\prime} \mathrm{N}$, longitude $40^{\circ} 27^{\prime} \mathrm{E}$, altitude $680 \mathrm{~m}$ above sea level) and Mardin (latitude $37^{\circ} 15^{\prime} \mathrm{N}$, longitude $40^{\circ} 49^{\prime} \mathrm{E}$, altitude $485 \mathrm{~m}$ above sea level) of South-Eastern Anatolia, Turkey provinces, during 2012-13 growing season and under rainfed conditions. Meteorological data are given Figure 1. Total rainfall was $571.4 \mathrm{~mm}$ and $527 \mathrm{~mm}$ in Diyarbakir and Mardin locations, respectively during growing period. The monthly average air temperature was $11.95{ }^{\circ} \mathrm{C}$ in Diyarbakir and $12.68{ }^{\circ} \mathrm{C}$ in Mardin during the research periods (November- June).

Treatments, plant materials, design and experimental procedure

Three commercial triticale cultivars (Ege Yildizi, Fahad-5 and Karma 2000) and two triticale lines which developed by Faculty of Agriculture, University of Dicle (Line DZT-01 and Line DZT-06) were used as a plant material in this study. Sowing was done with a plot drill in the third week of November in both locations. The experiment was conducted in a randomized complete block design with four replications. The size of experiment plot was $4.8 \mathrm{~m}^{2}$ ( $4 \mathrm{~m}$ long 6 rows with $20 \mathrm{~cm}$ apart). Seed rate for all genotypes was $450 \mathrm{~m}^{-2}$. The plots were fertilized with $60 \mathrm{~kg} \mathrm{~N} \mathrm{ha}^{-1}$ and $60 \mathrm{~kg} \mathrm{P}_{2} \mathrm{O}_{5} \mathrm{ha}^{-1}$ at sowing and $60 \mathrm{~kg} \mathrm{~N}^{-1}$ was applied at tillering stage. The trial was harvested by Hege-125 trial harvester machine on 24 June 2013. 


\section{Data collected and measurements}

Data on grain yield, test weight, thousand kernel weight (1000-kernel weight), chlorophyll content (SPAD value), protein content, starch content, wet gluten and zeleny sedimentation were recorded during experimentation. Grain yields $\left(\mathrm{kg} \mathrm{ha}{ }^{-1}\right)$, chlorophyll content (unit), protein content $(\%)$, wet gluten $(\%)$, starch content $(\%)$, zeleny sedimentation, test weight
( $\mathrm{kg} \mathrm{hL}^{-1}$ ) and thousand kernel weight (g) were examined according to Kizilgeci et al., (2017a)

\section{Statistical analysis}

Analysis of variance was performed using the SAS 98 statistical package and significant means were separated by the LSD test at the $5 \%$ probability level.

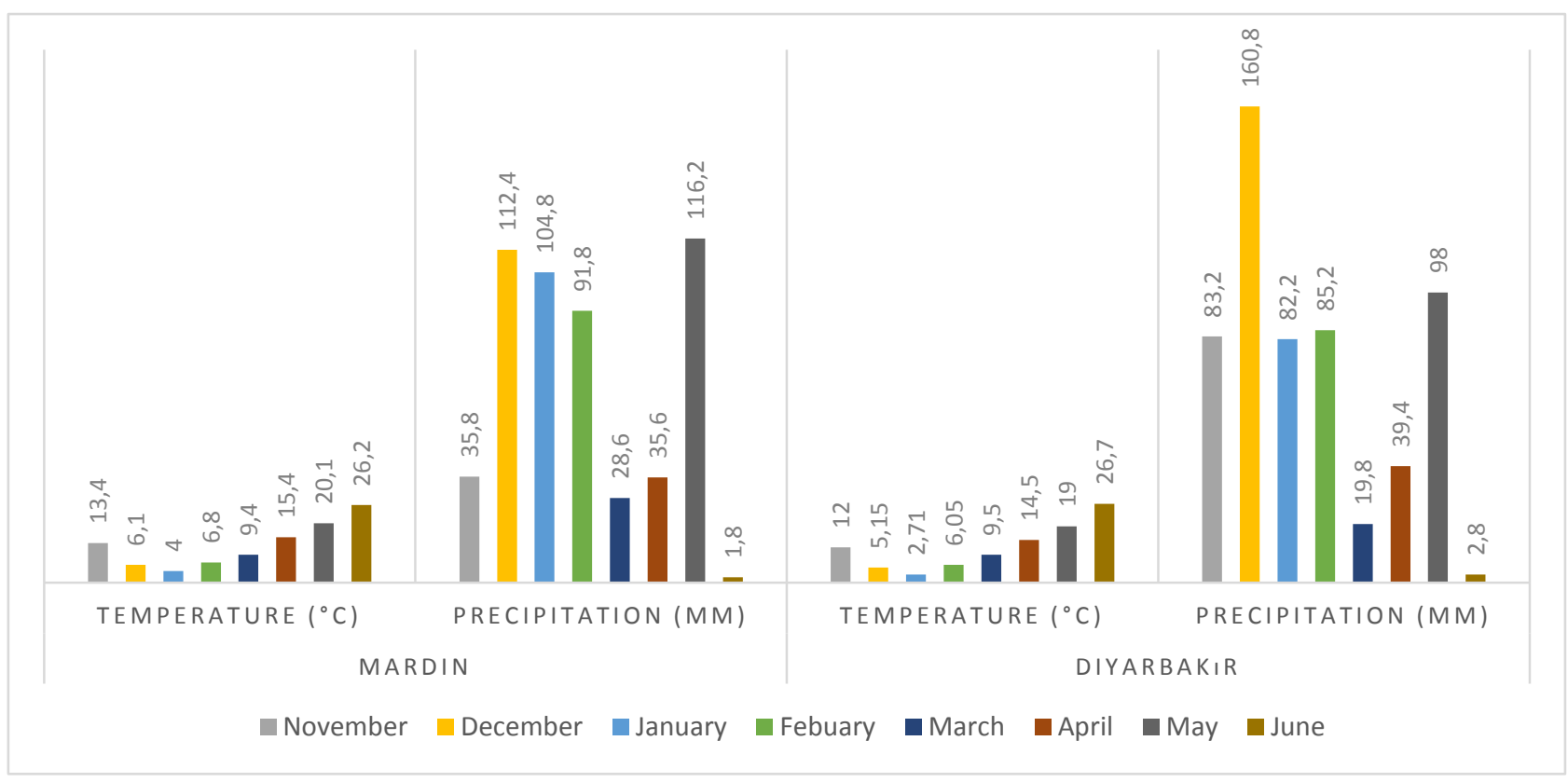

Figure 1. Meteorological data on temperature and precipitation during 2012-13 in both the locations

\section{RESULTS AND DISCUSSION}

The combined ANOVA for all studied traits showed highly significant differences among the locations, however SPAD value and thousand kernel weight were found non-significant. The differences among genotypes were found highly significant for SPAD value, grain yield, test weight and thousand kernel weight. Moreover, the genotype $\mathrm{x}$ location's interaction was found significant for SPAD, grain yield and thousand kernel weight (Table 1).

The mean SPAD value of all genotypes in both locations were ranged from 51.8 unit (DZT-01) to 57.3 unit (Line DZT-06). Among genotypes, the maximum SPAD value was obtained from Ege Yildizi (60.4 unit) in Diyarbakir location, while the lowest SPAD value was obtained from Line DZT-01 (48.0 unit) in Diyarbakir location. Chlorophyll contents (as SPAD units) were varied under due to different genetic makeup of the genotypes which were varied under two environmental conditions. The results of the present study related to the variation of SPAD value for different genotypes under multiple environmental conditions also confirmed by Giunta et al., (2002) indicated that triticale genotypes were ranged from 45.6 to 50.6 at heading stage. 
Among the location, the mean grain yield in the location Mardin (6027.8 $\left.\mathrm{kg} \mathrm{ha}^{-1}\right)$ was the highest than in Diyarbakır (5372.2 $\left.\mathrm{kg} \mathrm{ha}^{-1}\right)$. The mean grain yield of all genotypes in both locations was changed from $6469.3 \mathrm{~kg} \mathrm{ha}^{-1}$ to $5043.9 \mathrm{~kg} \mathrm{ha}^{-1}$. Whereas, the highest grain yield was obtained from DZT-06 $\left(6557.5 \mathrm{~kg} \mathrm{ha}^{-1}\right)$ in Mardin location, followed by Line DZT-01 $\left(6421 \mathrm{~kg} \mathrm{ha}^{-1}\right.$ ) in Diyarbakir location (Table 1). The study results revealed that the location Mardin produced the maximum grain yield than Diyarbakir. In the present study it is also indicated that due to the fact that genotypes have different responses to climatic condition, genotype $\mathrm{x}$ location interaction was found important. The observations also indicated that grain yield of triticale is variable parameter, which depends on numerous yield attributes and environmental factors. Various investigations have been noted that grain yield of triticale was significantly influenced by environmental conditions (Mut et al., 2006; Kendal and Sayar, 2016; Kizilgeci et al., 2017a; Kizilgeci et al., 2017b).

Table 1. Mean square estimates and mean performance of SPAD, yield and quality component value of triticale genotypes in Diyarbakir and Mardin locations

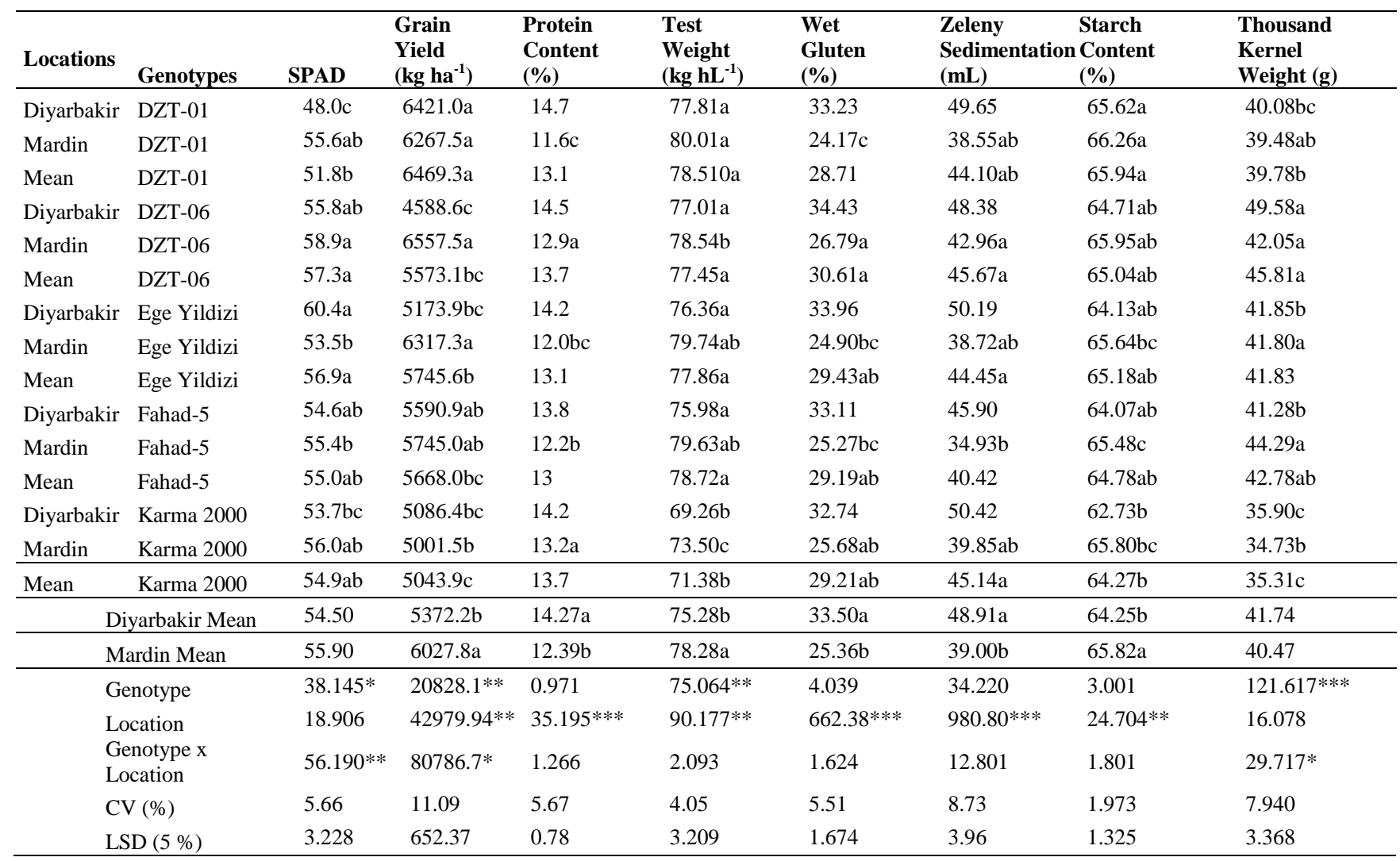

The protein content $(\mathrm{PC})$ of triticale is an important parameter. The mean protein content of all genotypes in both locations was varied from 13 to $13.7 \%$ and the maximum protein content was obtained from Line DZT-01 (14.7 $\%)$ in Diyarbakir location, while the minimum protein content obtained from also Line DZT-01 $(11.6 \%)$ in Mardin location. The mean protein content was changed from 14.2 to $14.7 \%$ in Diyarbakır location and from 11.6 to $13.2 \%$ in Mardin location (Table 1). Results showed that protein content was lower in Mardin location. However, low variation for this trait was observed among genotypes in Diyarbakir condition. Barutcular et al., (2016) reported that 
the protein content is affected by location, variety and environmental conditions.

The mean test weight (TW) genotypes of both locations was changed from $71.37 \mathrm{~kg} \mathrm{hL}^{-1}$ (Karma 2000) to $78.72 \mathrm{~kg} \mathrm{hL}^{-1}$ (Fahad-5). The mean test weight in Mardin location $(78.28 \mathrm{~kg}$ $\mathrm{hL}^{-1}$ ) was higher than in Diyarbakir location (75.28). The test weight was varied from 69.26 $\mathrm{kg} \mathrm{hL}^{-1}$ (Karma 2000) to $77.81 \mathrm{~kg} \mathrm{hL}^{-1}$ (Line DZT-01) in Diyarbakir and from $73.50 \mathrm{~kg} \mathrm{hL}^{-1}$ (Karma 2000) to $80.01 \mathrm{~kg} \mathrm{hL}^{-1}$ (Line DZT-01) in Mardin (Table 1). Among the genotypes, the Line DZT-01 had highest test weight in both locations. The test weight of triticale grain depends on the grain size, shape and density. Results of studies on different genotypes of triticale carried out by Mut et al. (2005), test weight ranged from 65.9 to $71.9 \mathrm{~kg} \mathrm{hl}^{-1}$.

Wet gluten content (WGC) and gluten quality are the main factors affecting the viscoelastic properties of triticale flour doughs. According to the wet gluten, the Line DZT-06 scored the highest mean value in both locations (30.61\%), while the Line DZT-01 revealed the lowest mean of both locations $(28.71 \%)$. The range of WGC was 32.74 (Karma 200) to 34.43 \% (Line DZT-06) in Diyarbakir location, while it reaches up to 24.17 (Line DZT-01) to $26.79 \%$ (Line DZT-06). These results showed that the wet gluten content in grains of all genotypes was influenced by the environmental condition in both locations. Kizilgeci et al., (2017a, b) also reported that the gluten content of grain was highly affected by environmental conditions and varied between 26.97 and $41.04 \%$.

The zeleny sedimentation (ZS) value assessment provides information on the protein quantity and the quality of flour. The average zeleny sedimentation value of both locations was varied from 40.42 to $45.67 \mathrm{~mL}$. The maximum zeleny sedimentation $(50.42 \mathrm{~mL})$ was achieved from the cultivar Karma 2000 in Diyarbakır location and the lowest value $(34.93 \mathrm{~mL})$ was achieved from Fahad-5 in Mardin location. The mean zeleny sedimentation in Diyarbakir location $(48.91 \mathrm{~mL})$ was higher than in Mardin location $(39.00 \mathrm{~mL})$. Similar to other quality parameters, Zeleny sedimentation in grains of all genotypes was influenced by the environmental condition in both locations. In an another observation, Kizilgeci et al., (2017a) found that zeleny sedimentation of some triticale genotypes varied between 42.29 and $50.38 \mathrm{~mL}$ in Diyarbakir condition and between 50.08 and $64.23 \mathrm{ml}$ in Mardin condition. Similarly, Atli (1999) noted that the difference sedimentation value in different genotypes were varied due to genotype as well as the climatic factor.

Starch plays a major role in some baking products. When investigated starch content of the locations, conducted the field experiment, the highest starch content (SC) was obtained from Mardin location (65.82\%), whereas the lowest starch content was observed in Diyarbakir location $(64.25 \%)$. The maximum mean starch content was obtained from Line DZT01(65.94\%), whereas the minimum starch content was obtained from Karma 2000 variety $(64.27 \%)$. The starch content value of study was changed from 62.73 to $66.26 \%$ among locations. Klassen et al., (1971) found that starch content of mature grain ranged from 49.1 to $57.1 \%$. Kučerová (2007) reported that the starch content was influenced by year, site and genotype.

The two-location average data belonging to thousand kernel weight (TKW) has been given in Table 1. The average of both locations for TKW varied between 35.31 and 45.81g and the maximum TKW was obtained from Line DZT-06 (49.58g) in Diyarbakir location, while the minimum TKW obtained from Karma 2000 variety $(34.73 \mathrm{~g})$ in Mardin location. The mean TKW was changed from 35.90 to $49.58 \mathrm{~g}$ in Diyarbakır location and from 34.73 to $44.29 \mathrm{~g}$ in Mardin location (Table 1). The variation of TKW among triticale genotypes may be due to the differences in the genetic make-up of the varieties. As well as the environmental factors in 
both locations. The result of the present study related to TKW is similar to the findings of Kizilgeci et al., (2017a) who reported TKW of some triticale genotypes changed from 29.89 to $45.21 \mathrm{~g}$ due to different environmental conditions.

Correlation coefficients between all investigated traits were given Table 2. Grain yield was found significantly correlated with TW $(\mathrm{r}=0.512 *)$ and TKW $(\mathrm{r}=0.707 *)$ in Mardin location. Similarly, Oral and Ulker (2016) and
Furan et al., (2005) observed a positive association of TKW with grain yield. Significant positive correlated between PC with WGC and ZS in both locations but significant negatively varied with TW (-0.712) in Mardin location and with SC $\left(r=0.510^{*}\right)$ in Diyarbakir. WGC also showed a significant positive correlation with ZS in both locations. Correlation coefficient of SC was negative significant with ZS $(-0.567 * *)$ in Diyarbakir location and with TKW $(r=-0.449 *)$ in Mardin location.

Table 2. Correlation coefficients between grain yield and quality component of triticale genotypes evaluated in Diyarbakir and Mardin locations

\begin{tabular}{|c|c|c|c|c|c|c|c|c|c|}
\hline Traits & Locations & SPAD & GY & $\mathrm{PC}$ & TW & WGC & $\mathrm{ZS}$ & $\mathrm{SC}$ & TKW \\
\hline SPAD & $\begin{array}{l}\text { Diyarbakir } \\
\text { Mardin }\end{array}$ & 1 & & & & & & & \\
\hline GY & $\begin{array}{l}\text { Diyarbakir } \\
\text { Mardin }\end{array}$ & $\begin{array}{l}-\mathbf{0 . 4 4 9} * \\
-0.115 \\
\end{array}$ & 1 & & & & & & \\
\hline $\mathrm{PC}$ & $\begin{array}{l}\text { Diyarbakir } \\
\text { Mardin }\end{array}$ & $\begin{array}{l}0.020 \\
0.325 \\
\end{array}$ & $\begin{array}{r}-0.135 \\
-0.097 \\
\end{array}$ & 1 & & & & & \\
\hline TW & $\begin{array}{l}\text { Diyarbakir } \\
\text { Mardin }\end{array}$ & $\begin{array}{l}-0.029 \\
-0.114 \\
\end{array}$ & $\begin{array}{l}0.330 \\
\mathbf{0 . 5 1 2} * \\
\end{array}$ & $\begin{array}{c}0.136 \\
-\mathbf{0 . 7 1 2} * \\
\end{array}$ & 1 & & & & \\
\hline $\mathrm{GC}$ & $\begin{array}{l}\text { Diyarbakir } \\
\text { Mardin }\end{array}$ & $\begin{array}{l}0.269 \\
0.355 \\
\end{array}$ & $\begin{array}{r}-0.085 \\
0.204 \\
\end{array}$ & $\begin{array}{l}0.748 * * \\
0.824 * * * \\
\end{array}$ & $\begin{array}{r}0.241 \\
-0.278 \\
\end{array}$ & 1 & & & \\
\hline $\mathrm{ZS}$ & $\begin{array}{l}\text { Diyarbakir } \\
\text { Mardin }\end{array}$ & $\begin{array}{l}0.243 \\
0.276 \\
\end{array}$ & $\begin{array}{l}0.051 \\
0.192 \\
\end{array}$ & $\begin{array}{l}0.691 * * \\
0.571 * * \\
\end{array}$ & $\begin{array}{r}0.006 \\
-0.213 \\
\end{array}$ & $\begin{array}{l}0.546 * \\
0.731 * * \\
\end{array}$ & 1 & & \\
\hline $\mathrm{SC}$ & $\begin{array}{l}\text { Diyarbakir } \\
\text { Mardin }\end{array}$ & $\begin{array}{r}-0.311 \\
0.276 \\
\end{array}$ & $\begin{array}{r}0.202 \\
-0.269 \\
\end{array}$ & $\begin{array}{l}\mathbf{- 0 . 5 1 0} * \\
-0.194\end{array}$ & $\begin{array}{r}0.304 \\
-0.005 \\
\end{array}$ & $\begin{array}{l}-0.424 \\
-0.244 \\
\end{array}$ & $\begin{array}{c}\mathbf{- 0 . 5 6 7} * * \\
0.255\end{array}$ & 1 & \\
\hline TKW & $\begin{array}{l}\text { Diyarbakir } \\
\text { Mardin }\end{array}$ & $\begin{array}{l}0.151 \\
0.040\end{array}$ & $\begin{array}{l}-0.432 \\
\mathbf{0 . 7 0 7} * *\end{array}$ & $\begin{array}{l}0.038 \\
-0.170\end{array}$ & $\begin{array}{l}0.272 \\
\mathbf{0 . 6 1 4} * *\end{array}$ & $\begin{array}{l}0.131 \\
0.196\end{array}$ & $\begin{array}{r}-0.248 \\
0.001\end{array}$ & $\begin{array}{c}0.211 \\
\mathbf{- 0 . 4 4 9} *\end{array}$ & 1 \\
\hline
\end{tabular}

*p< 0.05 (Significant at the 5\% level), **p< 0.01 (Significant at the 1\% level); ***p< 0.001 (Significant at the $0.1 \%$ level); GY: grain yield, PC: protein content, TW: test weight, WGC: wet gluten content, ZS: zeleny sedimentation, SC: stach content, TKW: thousand kernel weight

\section{CONCLUSION}

From the results and discussion of present study, it is indicated that genotypes were remarkably influenced by the changes at the grain yield and quality component. The highest values of grain yield were obtained in Mardin while the lowest values were observed in Diyarbakir location. In both location, Line DZT-01 produced the highest grain yield. The greatest disadvantage of triticale is that there is currently a limited market for the grain. This disadvantage can remove where growers can use the crop for livestock on farm. With regard to grain yield and some quality traits of Line DZT01 and quality traits of Line DZT-06 were highest than commercial cultivars in both locations. Line DZT-01 was found as promising line. These lines can new cultivar candidates and could be recommended to sown in South Eastern Anatolia Region of Turkey. 


\section{REFERENCES}

Atli A, 1999. Wheat and quality of its product. Symposium on the Problems and Solutions of Grain Crop in Central Anatolia, Konya, June 8-11, 1999, pp:498-506.

Barutcular C, Yildirim M, Koc M, Dizlek H, Akinci C, EL Sabagh A, Saneoka H, Ueda A, Islam MS, Toptas I,Albayrak O, Tanrikulu A, 2016. Quality traits performance of bread wheat genotypes under drought and heat stress conditions. Fresenius Environmental Bulletin, 25(10):1-7.

FAO, 2016. Food and Agriculture Organization of the United Nationals, http://www.fao.org/faostat/en/\#data/QC, (Accessed: 16 June 2016).

Furan MA, Demir I, Yuce S, Can RA, Aykut F, 2005. Research on Aegean Region Triticale Variety Development Studies and Relationships among Yield and Quality Components in the Developed Variety and Lines. Mediterranean Agricultural Sciences, 18(2):251-256.

Giunta F, Motzo R, Deidda M, 2002. SPAD Readings and Associated Leaf Traits in Durum Wheat, Barley and Triticale Cultivars. Euphytica, 125(2):197-205.

Kizilgeci F, Yildirim M, 2017a. Determination of Yield and Quality Components of Some Triticale (X Triticosecale Wittmack) Genotypes. Turkish Journal of Agricultural Research, 4(1):43-49.
Kizilgeci F, Akinci C, Albayrak O, Yildirim M, 2017b. Relationships of Grain Yield and Some Quality Parameters with Physiological Parameters in Some Triticale Advanced Lines. Iğdır University Journal of the Institute Science and Technology, 7(1): 337-345.

Kendal E, Sayar MS, 2016. The Stability of Some Spring Triticale Genotypes Using Biplot Analysis. The Journal of Animal and Plant Sciences, 26(3):754-765

Klassen AJ, Hill RD, Larter EN, 1971. Alphaamylase Activity and Carbohydrate Content as Related to Kernel Development in Triticale 1. Crop science, 11(2):265267.

Kučerová J, 2007. The Effect of Year, Site and Variety on The Quality Characteristics and Bioethanol Yield of Winter Triticale. Journal of the Institute of Brewing, 113(2):142-146.

Meyer R, Lorenzo del Rio AJ, 2004. Triticale As Animal Feed, Triticale Improvement and Production, 49-57.

Mut Z, Albayrak S, Tongel O, 2006. Determination of Grain Yield and Some Traits of Triticale (Xtriticosecale Wittmack) Lines. Journal of Agricultural Sciences, 12(1): 56-64.

Oral E, Ulker M, 2016. Path Analysis and Relations Between Features in Triticale (X Triticosecale Witmack) Varieties. Iğdır University Journal of the Institute Science and Technology, 6(3): 153-160. 